\title{
Civil Society and the Promotion of Human Security: Achievements, Limits, and Prospects
}

\author{
David R. Black
}

In the years immediately before and after the 1998 Lysøen Declaration, a striking feature of the initiatives associated with the human security agenda was the prominent role of civil society coalitions, which was widely regarded as indispensible to the signal successes of this period. However, the dramatic breakthroughs of this "new diplomacy" were the products of a propitious conjuncture of conditions that contained the seeds of their subsequent loss of momentum. Yet the human security work of civil society organizations (CSOs) continues, in less prominent but still important ways, to be woven into the fabric of the more cosmopolitan practices promoted by the agenda. In the meantime, their setbacks contain important lessons-both for CSOs and for the policymakers inclined to collaborate with them.

Keywords human security, civil society, new diplomacy, problem-solving theory, critical theory, emancipation

\section{Introduction}

In the years immediately before and after the 1998 Lysøen Declaration negotiated by Canada and Norway, ${ }^{1}$ when the policy influence and academic debate regarding the human security agenda was most intense, one of the most striking features of the initiatives associated with this agenda was the prominent role of nongovernmental or civil society coalitions. In short, almost as intensely debated as the content of the human security agenda was the innovative means by which it was advanced. While the role of non-state actors in catalyzing important ethical and political causes in international affairs was hardly unprecedented, ${ }^{2}$ the exponential growth in the numbers, prominence, and sophistication of these organizations and the campaigns they orchestrated was truly novel. For reasons that will be discussed in this article, their role was widely regarded as indispensible to the signal successes of the human security agenda, including, but certainly not limited to, the Landmines Convention, the Rome Treaty creating 
the International Criminal Court (ICC), and the principle of the Responsibility to Protect (R2P).

Fast forward a decade and a half and it appears that the breakthrough successes associated with this "new diplomacy" have dramatically slowed, if not stalled altogether, along with the idea of human security and human securitylinked initiatives themselves. How do we account for the prominent and influential role played by civil society organizations (CSOs) in the Lysøen era? How and why were CSOs so significant in this period of time? Why has their prominence and influence seemingly waned? And how do they continue to support the ideas and causes associated with human security, if not necessarily in such explicit terms?

I argue that the dramatic breakthroughs associated with CSOs and the new diplomacy were the products of a particularly propitious conjuncture of conditions and policy entrepreneurs in the dynamic decade following the end of the Cold War. Yet their very successes contained the seeds of their subsequent loss of momentum. Nevertheless, their work continues in a variety of less prominent, yet highly important, ways. In short, they have become woven into the fabric of the more cosmopolitan or solidaristic practices promoted by the human security agenda. In the meantime, their setbacks and frustrations contain important lessons-both for CSOs and CSO coalitions, and for the policymakers who are inclined to collaborate with them.

\section{The Civil Society-Human Security Interface: The Bridge between Two Bridging Constructs}

To address the ideas of civil society and human security together is to tackle two of the most notoriously elusive constructs in contemporary International Studies. Each of them is famous for their conceptual ambiguity; their uneasy combination of normative, descriptive, and prescriptive usages; and their boundary problems. In short, what is in and out of the ambit of both human security and civil society? Yet each has had a powerful appeal and influence, both conceptually and practically-not least in their relationship with each other. In particular, both are boundary or bridging ideas that force analysts and practitioners alike to connect different realms of knowledge and practice. It is precisely this integrative or bridging role, I argue, that makes them so challenging to operationalize, but is also at the root of their appeal.

Civil society has been characterized as "the sphere of ideas, values, institutions, organizations, networks, and individuals located between the family, the state, and the market" (Glasius, Kaldor, and Anheier 2001, 17). It does not take much reflection to come up with a list of boundary-confounding groupings within this exceptionally diverse and diffuse category of actors-for example, 
trade unions, business confederations, and so-called QUANGOs and GONGOs (quasi-government and government-operated nongovernmental organizations respectively, funded and/or penetrated by governments), all of which effectively straddle the boundary between civil society and its ostensible perimeters. Much attention has focused on global civil society, "operating beyond the confines of national societies, polities, and economies" (ibid.; Kaldor, Moore, and Slechow 2012) - and indeed, there has been exponential (though slowing) growth in the numbers of international nongovernmental organizations (INGOs). According to the Union of International Associations, the number of INGOs has increased from 22,334 in 1990, to 45,674 in 2000, to 55,853 in 2010 (cited by Anheier, Kaldor, and Glasius 2012, 19-20). But of course civil society also encompasses national and local variants, often more or less tightly connected to each other and to transnational networks (e.g., Keck and Sikkink 1998).

Civil society has been conceived both as a movement, embodying a "dynamic of claims and counter-claims for justice" (Anheier, Kaldor, and Glasius 2012, 10), and also, descriptively, as simply an arena of associational life between the family, state, and market. Similarly, one of the leading thinkers on global civil society, Mary Kaldor, has distinguished: (1) a social movement-based "activist version" of global civil society; (2) a tamed or "neoliberal version" of nongovernmental organizations that have become increasingly institutionalized and professionalized in the course of routine collaborations with governments and international organizations; and (3) a "postmodern version" encompassing more ascriptively based forms of association, such as those associated with ethnic and religious identities (Kaldor 2003, 588-591). A related classification distinguishes "supply side" and "demand side" organizations - the former providing "public goods or services alongside or in lieu of governments," and the latter focusing principally on "advocacy in order to change norms and government policies" (Haddad 2013 , 190). In practice, however, many organizations combine both of these roles, including major INGOs like Oxfam that have both robust advocacy and program-delivery roles; while in other cases CSOs and CSO coalitions shift the balance between these roles and identities over time. Finally, while civil society is often associated with progressive, more or less cosmopolitan, causes, it also incorporates more conservative, regressive, or "uncivil" elements, such as the "Astroturf" (vs. grassroots) Tea Party movement in the United States (Anheier, Kaldor, and Glasius 2012, 14).

Human security, for its part, is a famously broad and imprecise conceptso much so that many scholars and practitioners have argued that it has done more harm than good in advancing humane and humanitarian praxis. Most famously, it has encompassed exponents of both freedom from fear and freedom from want. This distinction has been characterized by Pauline Ewan (2007) as the debate between those favoring a holistic approach, encompassing both freedom from fear and from want, and "delimiters," championing a narrower emphasis 
on freedom from fear, mainly for reasons of conceptual clarity and policy applicability (Paris 2001; Krause 2004; MacFarlane and Khong 2006; Martin and Owen 2010). Closely connected to this, human security has encompassed an emphasis on both policy imperatives - often urgent - to respond to crises of human insecurity, and foundational theory concerning the ethical and structural premises of what it means to be secure. It has also drawn on different disciplinary ways of knowing (anthropological, economic, historical, political, sociological, etc.), and has straddled local, national and global levels of analysis, among other boundary-crossing transgressions.

In my view, the encompassing nature of human security has been, on balance, more a strength than a weakness. Specifically, I see the most interesting and promising (though challenging) feature of human security as its potential to provide, indeed require, a bridge between what Robert Cox famously characterized as problem-solving theory on the one hand, and critical theory on the other (Sinclair 1996, 4-6; Cox 1986). This seminal distinction is well known. Problem-solving theory accepts the basic parameters of the international system as it finds them, and seeks to ameliorate and "manage" the action within it; whereas critical theory steps outside the confines of the existing order to identify both its origins and the forces of change that contain the seeds of various alternative future orders. The distinction, therefore, also contains a vital ethical element. Critical theory, in taking a fundamentally historicized view of world orders and in studying the contradictions that point towards long-term change, highlights the potential to identify and work towards normatively preferable (that is, more just or emancipatory) future orders.

Even though Cox's own project was to elaborate a critical theoretical approach, he argued that both problem-solving theory and critical theory were inevitable and indeed necessary. This is clearly evident in the case of the manifold challenges of human insecurity-whether arising from complex humanitarian emergencies, civil and regional conflicts, or heinous weapons systems that indiscriminately victimize civilians. In such contexts, human security requires the elaboration of real-time responses to immediate crises and the human suffering associated with them-fundamentally a problem-solving imperative. On the other hand, and in parallel, it requires that these responses be tied to the analysis and pursuit of long-term processes of transformation towards normatively preferable futures, if they are to be more than repetitive palliations. In other words, human security highlights the need to link the pursuit of immediate relief of acute insecurity and suffering with longer-term emancipation, in the terms utilized by Critical Security Studies. ${ }^{3}$

I argue in this article that in many respects the interface between civil society and the state can be seen as the institutional manifestation of this critical theory/ problem-solving theory dynamic in relation to the theory and practice of human security. These two diverse and overlapping institutional forms encompass 
between them both the aspiration towards, and the possibility of combining, the immediate relief of human insecurity with the objective of reorganizing world politics in ways that reduce its recurrence. More to the point, without both pressure and engagement from the various forms of civil society organizationswhether activist, tamed, or postmodern-the advances that have been made in human security practice would not have been possible, while the prospect of more far-reaching or transformative change would be even more elusive than it often seems in the current context.

\section{Evaluating the Role of CSOs in the First Two Decades of Human Security}

What can be said about the roles and impact of CSOs in the first two decades of human security praxis, beginning with the UNDP's pathbreaking 1994 report? $^{4}$ First, it needs to be stressed that CSOs can both advance and undermine human security initiatives. As noted above, if there is one thing that has grown in studies of civil society in the past decade it is cynicism, as well as an understanding that along with its many progressive elements, civil society as a descriptive category also encompasses many regressive and/or disruptive elements (Anheier, Kaldor, and Glasius 2012, 14-15). There are numerous instances of such more or less "uncivil" behavior, including, for example, the vigorous campaigns of various powerful civil society groups to forestall the negotiation and signing of a global Arms Trade Treaty (ATT), and the advocacy by North American conservative Christian groups of regressive and punitive legislation towards lesbian, bisexual, gay, and transgendered (LGBT) people in African countries like Uganda (Hornsby 2014).

Second, however, civil society organizations and coalitions scored some striking successes, particularly during the first decade of the human security agenda, largely through the advent of what its protagonists termed the "new diplomacy." One of its principal exponents, former Canadian Foreign Minister Lloyd Axworthy, characterized this new diplomacy as "a new kind of global politics ... where nontraditional actors, citizen diplomats, have an important role to play in the formulation, promotion, and enactment of foreign policy." He went on, "The internationalization of conscience by these new actors has been an instrumental tool in the development and promotion of the human security agenda" (Axworthy 2001, 5). More scholarly treatments, such as that of Sandra Maclean and Tim Shaw, used the more prosaic terminology of "strategic mixed-actor coalitions," and were somewhat more cautious in highlighting the formidable obstacles to "getting from informal and transitory advocacy coalitions to more authoritative, continuing governance institutions..." (Maclean and Shaw $2001,30)$. However, in reading accounts from some of the practitioners who 
became deeply involved in these efforts it is hard not to be swept up in the sense of purpose and excitement they projected. Rob McRae, for example, emphasized the ramifications of new information and communication technologies in "accelerating [the work of civil society] movements in terms of the timescale for achieving their objectives [and offering up] a potentially global support base" (McRae 2001, 241). Reflecting the problem-solving orientation that predominated among Canadian and other practitioners, he asserted: "Interestingly, this emerging global civil society is not so much energized by ideology or even oldstyle politics, as by the very concrete, practical, and humanitarian concerns of the human security agenda" (247).

The roll call of new diplomacy successes is indeed formidable. ${ }^{5}$ Its better known achievements include, but are certainly not limited to: the Landmines Convention (the Ottawa Treaty); the Rome Treaty establishing the International Criminal Court (ICC); the Kimberley Process aimed at stemming the trade in "conflict diamonds" and various subsequent efforts to deal with "conflict minerals" such as the Publish What You Pay network; ${ }^{6}$ and the campaigns to foster new norms and capacities for the protection of civilians caught up in armed conflicts, with particular emphasis on war-affected children, and to foster a new Responsibility to Protect (R2P) their citizens on the part of states. ${ }^{7}$ Moreover, lest we think that these campaigns ended with $9 / 11$ and the onset of the "global war on terror," it is worth reminding ourselves of more recent successes, such as the Oslo Process leading to the negotiation of the Convention on Cluster Munitions in 2008 (Nash 2012).

The results of these and other campaigns have been more and less comprehensive and enduring. Some (for example, with regard to R2P) have had remarkable breakthroughs at the level of "entrepreneurial leadership," but have bogged down at the level of "implementation leadership" - that is, translating normative principles into real, widespread advances in the human security of affected individuals. ${ }^{8}$ Others (for example, in the realm of human rights or the operationalization of the ICC) have triggered adaptive responses and backlashes that have partially undone the progress made, or at least triggered deep resentments and resistance. ${ }^{9}$

Nevertheless, and notwithstanding numerous controversies and periodic setbacks, these various initiatives have represented real steps forward in the promotion of a more solidaristic or cosmopolitan approach towards security policy-steps towards the institutionalization of a new concern with human security. In every case, moreover, they would not have been achievable without active leadership, participation and collaboration between coalitions of nonstate actors on the one hand, and policy entrepreneurs from like-minded states and international organizations on the other. This co-dependence was explicitly acknowledged by two Canadian diplomats closely involved in the process behind the Landmines Convention, who candidly noted that "it was civil society that 
made the treaty possible, and through the ICRC [International Committee of the Red Cross] and ICBL [International Campaign to Ban Landmines], contributed to the drafting of its provisions" (Gwozdecky and Sinclair 2001, 37). Thus, these landmark achievements demonstrated the potential, and indeed the necessity, of forging effective, durable, and adaptable "coalitions of convenience"-contingent coalitions around shared objectives. And, although the onset of this trend was doubtless foreshadowed by campaigns in earlier eras (Clark 2013, 55-73), it dramatically accelerated and was consolidated in conjunction with the human security agenda. ${ }^{10}$

What explains the success of these novel, mixed-actor coalitions, and in particular the impact of CSOs in enabling them? While a comprehensive account is beyond the scope of this brief article, a number of common factors stand out:

- A propitious global political environment in the aftermath of the Cold War and the empowering successes of transnational civil society in Eastern Europe, Latin America, and South Africa (Kaldor 2003; Risse, Ropp, and Sikkink 1999; Van Rooy 2004): In this new era of fluidity and optimism, the demonstration effects of successful national and transnational campaigns were powerfully felt. Concomitantly, in the scholarly literature the growth of anti-statism on both the right (neoliberalism) and the left (post-structuralism) encouraged a new enthusiasm for, and openness to, civil society initiative.

- The advent of new information and communication technologies that, as noted above, dramatically increased the speed and reach of civil society mobilizationoften (as in the case of the ICBL) from relatively remote and modest "headquarters" (McRae 2001; Gwozdecky and Sinclair 2001).

- Energetic and imaginative leadership, from both civil society coalitions and from a small group of receptive, activist-oriented policymakers: On the civil society side, capable, strategic, and compelling leaders, such as Jody Williams of the ICBL and William Pace of the Coalition for the International Criminal Court (CICC), achieved something close to celebrity status-a status that was firmly reinforced when Williams and the ICBL were awarded the Nobel Peace Prize in 1997. Of course, the fact that they were increasingly in cahoots with real celebrity diplomats, such as Bono, Bob Geldof, Princess Diana, Desmond Tutu, and various Hollywood luminaries, strongly reinforced their notoriety. But just as important was the fact that they were readily engaged by state-based policy entrepreneurs who, confronted by entrenched and conservative bureaucratic and political interests, saw in civil society coalitions a means of enhancing their own leverage and outflanking statebased forces of resistance. ${ }^{11}$

- The element of surprise: The very fact that these new forms of diplomatic engagement were so novel, thereby catching traditional centers of state-based and global political power flat-footed. Elements of this novelty included their ability to mobilize media and popular interest/pressure, their capacity in doing so to frame agendas, and the extraordinary degree of access they were able to gain to sympathetic political leaders and policy makers. 
Like virtually all apparent breakthroughs in international practice, however, the enthusiasm for the new diplomacy tended to obscure the risks and limits of these forms of mobilization, and set the stage for a predictable backlash. Notwithstanding these early successes, the sense one gets from many enthusiastic accounts of this period-that these innovative coalitions were producing an irreversible paradigm shift in the way we think about and do security policy-has proved overly optimistic. In short, the role of these civil society-state coalitions has proved fraught, contingent, and at least partially reversible. Moreover the excitement concerning the potentially emancipatory role of global civil society has, as noted earlier, given way to growing disaffection and cynicism. Why has the number and pace of breakthroughs stalled, or at least dramatically slowed?

\section{Explaining Reaction}

A number of factors help to explain this trend. First, the new diplomacy may have initially caught vested interests by surprise, but they quickly learned and adapted. Some of this learning has taken the form of preemptive restrictions on transnationally aligned NGOs and CSOs. One clear and striking example, albeit more concerned with human rights than human security per se, is the way in which the organizers of the Beijing Olympics (2008) learned from what had happened in the months preceding the Seoul Games (1988) and, through preventive suppression, ensured that the potential for social mobilization was forestalled long before the run up to the Beijing Games themselves (Black and Bezanson 2004). Similarly, new NGO legislation in countries such as Ethiopia has served to restrict anything that can be construed as "political" activity by international and internationally funded CSOs. In the specific case of Ethiopia, the Charities and Societies Proclamation, adopted in 2008, effectively headed off a recurrence of the popular mobilization that challenged the Zenawi regime following the 2005 election - the violent suppression of which significantly complicated Ethiopia's relations with international donors. Over the longer term, the Proclamation has also chilled and stifled any NGO work in the country that can be seen to have a political or human rights bent (Amnesty International 2012).

Moreover, within the like-minded states that were the principal advocates and partners of CSOs in human security initiatives, activist politicians and officials used coalitions with these non-state actors to overcome resistance inside their own political and bureaucratic establishments. In so doing, however, these state-based activist policymakers attracted bureaucratic resentment and resistance towards such unconventional alliances and methods. The effect was to constrain their scope and influence. In some cases at least, these activist officials perceived themselves-and were perceived by others within the bureaucracy-as 
what might be termed "insurgent bureaucrats" who, like insurgents everywhere, prompted the mobilization of more conservative interests in reaction. The coalitions underpinning the new diplomacy rested, in other words, on strategic codependence between groups within both states and civil societies, and as a result rendered both vulnerable.

Second, for many CSOs and NGOs, especially in what Alison Brysk (2009) has termed "global good Samaritan" states, ${ }^{12}$ the access, opportunities, and resources flowing from the new diplomacy led to the compromising of key aspects of their core mission. In short, their critical distance from state power-holders was compromised and their advocacy role was muted. As discussed above, there is a wide range of CSOs pursuing an array of distinct tactical and strategic orientations. Kaldor's activist version, for example, works from the "outside" in the realm of transnational social movements, and focuses on the mobilization of broadly based social pressure for global social justice and transformation. Her neoliberal version of tamed social movements that manifest as NGOs typically specialize in the "inside game" of service provision and collaboration with statebased institutions. The postmodern version encompassing many religious, ethnic, or hometown groups, often though not only in the Global South, inclines toward a variety of more informal techniques of influence, often in tension with the activities and identities of "modern" CSOs in the activist and neoliberal molds. Notwithstanding this diversity, however, the collective impact of CSOs and NGOs depends on their retaining a vital link to more critical analyses and radical possibilities.

The opportunity for close collaboration with governments, no matter how worthy the cause, also brings with it expectations of institutionalization and professionalization that tend to dull the radical edge of CSOs and dissipate their emancipatory intent. This dynamic is often gradual and insidious. It gets placed into sharp relief, however, when CSOs' erstwhile state-based allies are displaced by others adopting a much more distant, if not actively hostile, view of non-state actors. In effect, this is what has unfolded in Canada over the past eight years, with the Conservative government of Prime Minister Stephen Harper adopting a much more distant and suspicious approach towards the CSOs and NGOs that had come to take for granted a relatively benign and cooperative relationship with Canadian state-based actors. The process has left CSOs that were previously viewed as partners in implementing key aspects of the human security agenda reeling (Smillie 2012; Plewes and Tomlinson 2013). The Canadian experience serves as a salutary reminder that, whatever the popular profile and impact of NGOs, states-particularly in the OECD world ${ }^{13}$-enjoy institutional and resource capacities that give them major advantages over non-state actors in the medium- to long-term.

Third, the issue-specific, niche-based formula for success used to such effect in, for example, the Ottawa and Oslo Processes and the campaign for 
the creation of the ICC, is structurally self-limiting by virtue of the intensity of its focus and demands. Early entrants to this arena of causes and coalitionslike the ICBL or the CICC-benefited from an exceptionally high level of press, popular, and political interest that was, in turn, instrumental to the achievement of their objectives. However, as a proliferating array of coalitions championing other causes attempt to repeat the tactical and strategic formulas that led to earlier breakthroughs, the marketplace of causes becomes so fragmented and competitive that it becomes exceptionally difficult to secure and sustain the breadth and depth of interest that was so crucial to the success of the early entrants. Moreover, the demands of coalition mobilization and maintenance associated with these campaigns are extraordinary. The ICBL, for example, was "a loose network of 1200 organizations worldwide, whose power derived from a combination of dedication and new technology" sustained over many years (Gwozdecky and Sinclair 2001, 37). Similarly, the Cluster Munition Campaign (CMC) that was instrumental in the successful negotiations for the Convention on Cluster Munitions signed in 2008, involved 400 organizations in around 100 countries, requiring an exacting balance of adroit leadership, technical sophistication, and inclusive consultation persisting over a period of years (Nash 2012). Simply stated, this is a hard model to sustain and replicate.

Finally, while the new diplomacy was far more inclusive and participatory than traditional state-centric diplomacy, its democratizing potential has run up against some crucial limits that have impaired its legitimacy and effectiveness. The question becomes: Which civil society voices are successful in gaining access and being heard in the councils of power? And which ones, in the proliferating universe of CSOs, are marginalized?

Of particular importance in this regard is the degree to which the new diplomacy, and the human security innovations that flow from it, have been able to stretch in order to encompass and take seriously the voices, needs, and priorities of local communities and their representatives-that is, indigenous or local civil societies which are often at the epicenter of human insecurity (Richmond 2012/13; Ewan 2007). For example, in the emerging civilian protection regime, to what extent are international NGOs, states, and organizations truly responsive to, and able to collaborate constructively with, the self-protection efforts of civilians and communities that are "the first and last guarantors of their own security" (Suarez 2012)?

In general, despite routine invocations of the importance of indigenous civil society and local ownership, the champions of human security in global civil society have done less well than they should in seeing, hearing, and prioritizing these local, community-based groups and needs. We see this in a wide range of issues and contexts-for example, in the deep local controversies that have accompanied ICC indictments in a succession of African countries, reflecting the profound wariness among many Africans of this human security "triumph." The 
general failure to adequately engage and respond to local manifestations of civil society has undermined the legitimacy and the effectiveness of the campaigns championed by global civil society, and has reinforced the widely held perception that it has become, wittingly or unwittingly, a Trojan horse for Western interests (e.g., Hearn 2007).

\section{Has the New Diplomacy Run Its Course?}

It is tempting to conclude, in light of these challenges, suspicions, and limitations, that the breakthroughs of the late 1990s and early 2000s were a product of a particularly propitious conjunctural moment, and that they were ultimately time-bound and unsustainable. Of course, in many respects the landscape of international diplomacy has changed permanently, with a much more complex range of actors, partnerships, and techniques to be managed, and a proliferating range of wicked challenges to be addressed. From this perspective, the dynamism introduced to the human security agenda by the active participation and collaboration of CSO coalitions will not be recaptured.

There would be some truth to this conclusion, but it would also be overstated and premature. For one thing, the early and spectacular breakthroughs associated with the entrepreneurial leadership phase of the human security agenda, orchestrated by novel mixed-actor coalitions, were bound to be followed by a much longer, harder, and less spectacular process of figuring out how to implement these new principles and ideas. For example, how do those responsible (in civil society, governments, and inter-governmental organizations) actually do civilian protection in complex emergencies and civil conflicts? How can they blend the work of the ICC with other forms of transitional justice-or, more broadly, with social healing as defined and prioritized by affected communities? How can they intervene with life-saving humanitarian assistance in ways that do not play into the hands of repressive regimes by freezing displaced populations in locations and conditions of bare subsistence? And so on.

Much of this work continues, and civil society groups are essential to it, both conceptually and practically. Some of this work demands that CSOs, whose original raison d'etre was mobilization and advocacy, transition, in whole or in part, to new roles involving service provision, monitoring, accountability, etc. For example, in an illuminating article Heidi Nichols Haddad tracks and analyzes how the CICC, initiated as "a purely advocacy-oriented or demandside NGO coalition," underwent an unanticipated process of "hybridization" towards "an increasingly supply-side NGO coalition that provides services such as administrative support, judicial monitoring, and outreach," broadly in collaboration with the ICC (Haddad 2013, 190). In other cases, new CSOs and NGOs have emerged to work through and carry forward the ramifications of the 
normative breakthroughs made by earlier advocacy coalitions. For example, the Romeo Dallaire Child Soldiers Initiative (RDCSI) is a small but rapidly growing organization that in recent years has started to make remarkable progress in raising awareness and elaborating doctrine to address and roll back the use of, children as weapons of war-particularly among the security forces that have typically been viewed as incorrigible by earlier generations of social activists. ${ }^{14}$

More broadly, just as more conservative vested interests associated with states, interstate organizations, and some private sector interests have adapted to the novelty and challenges of the new diplomacy, CSOs and their allies can also be expected to learn and adapt. As they do so, however, there are a couple of key lessons - and tensions - that will need to be kept in mind. First, among both state and non-state partners in the erstwhile new diplomacy, there is a need to sustain a degree of critical distance from each other. Amongst CSOs, while some will continue to play the inside game in relation to state and interstate organizations with both positive and less positive results, the sector as a whole must relearn the lesson that its strength comes from sustaining a vital connection with more transformative ideas and objectives. In this connection, it must find innovative ways to bridge its problem-solving and critical impulses. Writing with regard to the relationship between CSOs and national human rights institutions (NHRIs) in Asia, Renshaw $(2012,312)$ captures the kind of dynamic that needs to be fostered: "It is possible that the relationship will always be one of fundamental tension.... The challenge is to ensure that the inevitable tension is a productive one." Similarly, greater efforts need to be made to become much more mindful of, and responsive to, local dynamics and groups. There is a requirement, in other words, to transcend what Frederic Megrét (2009) terms the "salvation paradigm."

Second, bridges must be built between various cause-based coalitions. There is a need, in other words, to promote a new kind of human security synthesis that may or may not use the language of human security, but that strives to capture its normative essence, within and across countries. The often extraordinary, but increasingly fragmented, efforts of dozens of such cause-based coalitions must be re-embedded within a larger vision of transformative politics if the structural underpinnings of ongoing human insecurity are to be collectively identified, analyzed, and addressed over the medium and long term.

\section{Notes}

1. For the text of the declaration and a discussion of the network that arose from it, see Small 2001, 231-235.

2. Witness the role of various non-state actors and advocacy networks in, for example, the 19th century campaigns to end the slave trade and foster international humanitarianism, or the post-World War II mobilizations in support of decolonization and 
human rights. See Barnett 2011; Risse, Ropp, and Sikkink 1999.

3. Emancipation is "the controversial heart of security studies." Ken Booth defines it (in part) as "the theory and practice of inventing humanity, with a view to freeing people, as individuals and collectivities, from contingent and structural oppressions.... The concept of emancipation shapes strategies and tactics of resistance, offers a theory of progress for society, and gives a politics of hope for common humanity." (Booth 2005, 181; see also 181-255).

4. See UNDP 1994.

5. For a Canada-centric but nevertheless illuminating sample of "new diplomacy" activism in the realm of human security, see McRae and Hubert 2001.

6. See, http://www.publishwhatyoupay.org (accessed August 19, 2014).

7. See, for example, www.childsoldiers.org (accessed August 19, 2014).

8. Think, for example, of the repercussions of the different crises in Libya and Syriaboth of which have brought the progress of R2P into serious question, albeit for very different reasons.

9. As manifested in widespread African reaction to the activities of the ICC, which have thus far been concentrated almost exclusively in that continent.

10. In a January 2013 public lecture, David Malone-one of the foremost scholars of the UN Security Council as well as a noted diplomatic practitioner-reflected that in the 20-plus years since the end of the Cold War, one of the most striking and unanticipated developments in relation to the UN Security Council was the explosive growth in the presence and engagement of NGOs and CSOs. The same is true of the nexus of issues and causes that came to compose the human security agenda.

11. On Axworthy's attitudes in this regard, see Donaghy 2003, 42.

12. Defined, rather idealistically, as states that "identify the national interest with global interests," and that "overcome their bounded origins as sovereign security managers to act as 'global citizens"' (Brysk 2009, 4).

13. The 34-member Organization for Economic Co-operation and Development, encompassing the world's most advanced capitalist countries including a growing number of rising or emerging economies.

14. In the interests of full disclosure, I should note that the RDCSI is based out of the research center that I directed from 2008-2014.

\section{References}

Amnesty International. 2012. "Ethiopia: Stifling Human Rights Work: The Impact of Civil Society Legislation in Ethiopia." March 12. http://www.amnesty.org/en/library/info/ AFR25/002/2012/en (accessed August 19, 2014).

Anheier, Hemut, Mary Kaldor, and Marlies Glasius. 2012. "The Global Civil Society Yearbook: Lessons and Insights 2001-2011.” In Global Civil Society 2012: Ten Years of Critical Reflection, eds. Mary Kaldor, Henrietta L. Moore, and Sabine Slechow. New York: Palgrave Macmillan, 2-26.

Axworthy, Lloyd. 2001. "Introduction." In Human Security and the New Diplomacy: Protecting People, Promoting Peace, eds. Rob McRae and Don Hubert. Montreal and Kingston: McGill-Queen's University Press, 3-13. 
Barnett, Michael. 2011. Empire of Humanity: The History of International Humanitarianism. Ithaca: Cornell University Press.

Black, David, and Shona Bezanson. 2004. "The Olympic Games, Human Rights, and Democratisation: Lessons from Seoul and Implications for Beijing." Third World Quarterly 25 (7): 1245-1261.

Booth, Ken, ed. 2005. Critical Security Studies and World Politics. Boulder: Lynne Rienner.

Brysk, Alison. 2009. Global Good Samaritans: Human Rights as Foreign Policy. New York: Oxford University Press.

Clark, Joe. 2013. How We Lead: Canada in a Century of Global Change. Toronto: Random House Canada.

Cox, Robert. 1986. "Social Forces, States, and World Orders." In Neorealism and Its Critics, ed. Robert Keohane. New York: Columbia University Press, 204-254.

Donaghy, Greg. 2003. "All God's Children: Lloyd Axworthy, Human Security and Canadian Foreign Policy, 1996-2000." Canadian Foreign Policy 10 (2): 39-56.

Ewan, Pauline. 2007. "Deepening the Human Security Debate: Beyond the Politics of Conceptual Clarification.” Politics 27 (3): 182-189.

Glasius, Marlies, Mary Kaldor, and Helmut Anheier, eds. 2001. Global Civil Society 2002. Oxford: Oxford University Press.

Gwozdecky, Mark, and Jill Sinclair. 2001. "Landmines and Human Security." In Human Security and the New Diplomacy: Protecting People, Promoting Peace, eds. Rob McRae and Don Hubert. Montreal and Kingston: McGill-Queen's University Press, 28-40.

Haddad, Heidi Nichols. 2013. "After the Norm Cascade: NGO Mission Expansion and the Coalition for the International Criminal Court." Global Governance 19 (2): 187-206.

Hearn, Julie. 2007. "African NGOs: The New Compradors?" Development and Change 38 (6): 1095-1110.

Hornsby, David. 2014. “The Tragedy of Uganda’s Anti-Gay Bill.” Canadian International Council, March 4. http://opencanada.org/features/blogs/roundtable/the-tragedy-ofugandas-anti-gay-bill/ (accessed August 19, 2014).

Kaldor, Mary. 2003. “The Idea of Global Civil Society." International Affairs 79 (3): 583-593.

Kaldor, Mary, Henrietta L. Moore, and Sabine Slechow, eds. 2012. Global Civil Society 2012: Ten Years of Critical Reflection. New York: Palgrave Macmillan.

Keck, Margaret E., and Kathryn Sikkink. 1998. Activists beyond Borders: Advocacy Networks in International Politics. Ithaca: Cornell University Press.

Krause, Keith. 2004. “The Key to a Powerful Agenda, If Properly Delimited." Security Dialogue 35 (3): 367-368.

MacFarlane, Neil, and Y.F. Khong. 2006. Human Security and the UN: A Critical History. Bloomington: Indiana University Press.

MacLean, Sandra J., and Timothy M. Shaw. 2001. "Canada and New 'Global' Strategic Alliances: Prospects for Human Security at the Start of the $21^{\text {st }}$ Century." Canadian Foreign Policy 8 (3): 17-36.

Martin, Mary, and Taylor Owen. 2010. “The Second Generation of Human Security: Lessons from the UN and EU Experience." International Affairs 86 (1): 211-224.

McRae, Rob. 2001. "Human Security, Connectivity, and the New Global Civil Society." In Human Security and the New Diplomacy: Protecting People, Promoting Peace, eds. Rob McRae and Don Hubert. Montreal and Kingston: McGill-Queen's University Press, 236-249. 
McRae, Rob, and Don Hubert, eds. 2001. Human Security and the New Diplomacy: Protecting People, Promoting Peace. Montreal and Kingston: McGill-Queen's University Press.

Mégret, Frederic. 2009. "Beyond the 'Salvation' Paradigm: Responsibility to Protect (Others) vs. the Power of Protecting Oneself." Security Dialogue 40 (6): 575-595.

Nash, Thomas. 2012. "Civil Society and Cluster Munitions: Building Blocks of a Global Campaign." In Global Civil Society 2012: Ten Years of Critical Reflection, eds. Mary Kaldor, Henrietta L. Moore, and Sabine Slechow. New York: Palgrave Macmillan, 124141.

Paris, Roland. 2001. “Human Security: Paradigm Shift or Hot Air?” International Security 26 (2): 87-102.

Plewes, Betty, and Brian Tomlinson. 2013. "Canadian CSOs and Africa: The End of an Era?” In Canada among Nations 2013. Canada-Africa Relations: Looking Back, Looking Ahead, eds. Robinson Medhora and Yiagadeesen Samy. Waterloo: Centre for International Governance Innovation and Carleton University, 213-226.

Renshaw, Catherine Shanahan. 2012. "National Human Rights Institutions and Civil Society Organizations: New Dynamics of Engagement at Domestic, Regional, and International Levels." Global Governance 18 (3): 299-316.

Richmond, Oliver P. 2012/13. "Human Security and its Subjects." International Journal LXVIII (1): 205-225.

Risse, Thomas, Stephen Ropp, and Kathryn Sikkink, eds. 1999. The Power of Human Rights: International Norms and Domestic Change. Cambridge: Cambridge University Press.

Sinclair, Timothy. 1996. "Beyond International Relations Theory: Robert W. Cox and Approaches to World Order." In Approaches to World Order, eds. Robert W. Cox and Timothy J. Sinclair. Cambridge: Cambridge University Press.

Small, Michael. 2001. "The Human Security Network." In Human Security and the New Diplomacy: Protecting People, Promoting Peace, eds. Rob McRae and Don Hubert. Montreal and Kingston: McGill-Queen's University Press, 231-235.

Smillie, Ian. 2012. "Tying up the Cow: CIDA, Advocacy, and Public Engagement." In Struggling for Effectiveness: CIDA and Canadian Foreign Aid, ed. Stephen Brown. Montreal and Kingston: McGill-Queen's University Press, 269-286.

Suarez, Carla. 2012. "Survival in the Everyday of Armed Violence." Canadian International Council, OpenCanada.org. November 27. http://opencanada.org/features/the-thinktank/essays/survival-in-the-everyday-of-armed-violence/ (accessed August 19, 2014).

UNDP (United Nations Development Programme). 1994. Human Development Report 1994. New York: Oxford University Press. http://hdr.undp.org/sites/default/files/ reports/255/hdr_1994_en_complete_nostats.pdf (accessed August 19, 2014).

Van Rooy, Alison. 2004. The Global Legitimacy Game: Civil Society, Globalization, and Protest. New York: Palgrave Macmillan.

David Black is Lester B. Pearson Professor of International Development Studies and Professor of Political Science at Dalhousie University in Halifax. He was previously Chair of the Department of IDS and Director of the Centre for Foreign Policy Studies. He has also served as co-Director of the Canadian Consortium on Human Security. His publications include The International Politics of Mass 
Atrocities: The Case of Darfur (co-edited with Paul Williams) (Routledge, 2010); A Decade of Human Security (co-edited with Sandra MacLean and Timothy Shaw) (Ashgate 2006); and a Special Issue of Canadian Foreign Policy Journal on "Canadian Multilateralism: Past, Present, Future" (co-edited with Greg Donaghy) (2010).E-mail: David.Black@dal.ca 